width and depth, and extenting for some ro yards. A sprucetree close by shows a furrow an inch in width running from a height of 6 feet down to the root.

ON Thursday night, at II.30, M. L'Hoste crossed from Cherbourg in a balloon, alighting in the neighbourhood of London at 6.30 on Friday morning. M. L'Hoste had a small sail to assist in directing the balloon, and an apparatus for letting down into the sea to draw water into the balloon to act as ballast. He was accompanied by M. Mangot, the astronomer. The highest altitude attained was 3600 feet, and the lowest temperature observed $7^{\circ} \mathrm{C}$.

THE additions to the Zoological Society's Gardens during the past week include a Malbrouck Monkey (Cercopithecus cynosuru:) from West Africa, presented l,y Mrs. Barrington; a Blue-faced Amazon (Chrysotis astiva) from Brazil, presented by Mrs. J. Fletcher ; an Aldrovandis Skink (Plistiudon auratus) from North Africa, presented by Mr. R. J. M. Teil; two Grey Parrots (Psittacus erithacus) from West Africa, deposited; a Sea Eagle (Haliaetus -), a Masked Weaver Bird (Hyphantornis personata) from Africa, a Short-eared Owl (Asio brachyotus), European, a Hyacinthine Macaw (Ara hyacinthina) from North Brazil, two Blanding's Terrapins (Clemmys blandingi) from North America, two Indian River Snakes (Tropidonotus quincunciatus) from India, purchased; two Triangular Spotted Pigeons (Columba guinea), a Geoffroy's Dove (Peristera geoffroii), four Brazilian Teals (Querquedula brasiliensis), five Slender Ducks (Anas gibberifrons), two Chilian Pintails (Dafila spinicauda), two Wild Ducks (Anas boschas), a Himalayan Monaul (Lophophorus impeyanus), bred in the Gardens.

\section{ASTRONOMICAL PHENOMENA FOR THE WEEK 1886 AUGUST 8-14}

(FOR the reckoning of time the civil day, commencing at Greenwich mean midnight, counting the hours on to 24 , is here employed.)

\section{At Greenwich on August 8}

Sun rises, 4 h. $37 \mathrm{~m}$.; souths, $12 \mathrm{~h} .5 \mathrm{~m} .25 \cdot 3$. ; sets, $19 \mathrm{~h} .34 \mathrm{~m}$. ; decl. on meridian, $16^{\circ} 6^{\prime}$ N. : Sidereal Time at Sunset, I6h. $43 \mathrm{~m}$.

Moon (two days after First Quarter) rises, 14h. $45 \mathrm{~m}$.; souths, 19h. $25 \mathrm{~m}$.; sets, oh. $1 \mathrm{~m}$. ; decl. on meridian, $16^{\circ} 4 \mathrm{I}^{\prime} \mathrm{S}$.

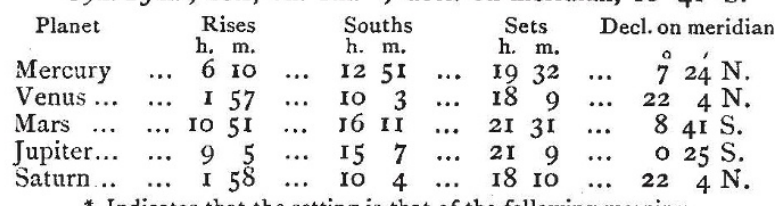
* Indicates that the setting is that of the following morning.

\section{Irariable Stars}

Star

$$
\text { R.A. Decl. }
$$

h. m. $\quad$. $8^{\circ}$.

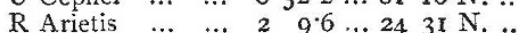

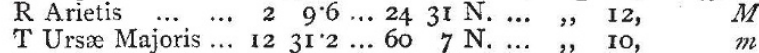

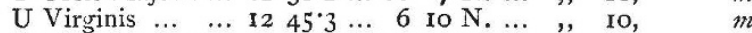
R Camelopardalis. $1426.3 \ldots 842$ I N. ...

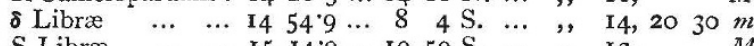

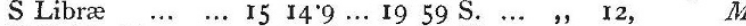

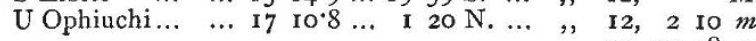

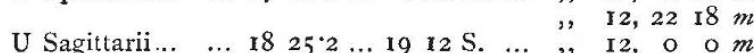

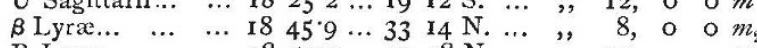

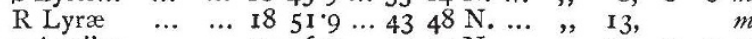

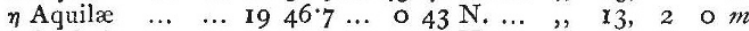

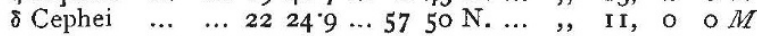
$M$ signifies maximum; $m$ minimum; $m_{2}$ secondary minimum.

Meteor Showers

The principal shower of the week is that of the Perseids, R.A. $43^{\circ}$, Decl. $56^{\circ} \mathrm{N}$. The maximum occurs on August Io, but many meteors from the same radiant are usually seen on the nights both immediately preceding and following that date. Meteors are frequently seen also from neighbouring radiants, e.o. near the Pleiades, R.A. $55^{\circ}$, Decl. $26^{\circ}$ N. ; near Capella, R.A. $68^{\circ}$, Decl. $46^{\circ}$ N. ; near $\nu$ Tauri, R.A. $55^{\circ}$, Decl. $7^{\circ}$ N.; and from Lynx, R.A. $96^{\circ}$, Decl. $7 \mathrm{I}^{\circ}$ N. A radiant from a Pegasi, R.A. $345^{\circ}$, Decl. $15^{\circ}$ N.; is also active at this season, which is usually the most prolific of the year.

Oicultations of Stars by the Moon (visible at Greenwich)

\begin{tabular}{|c|c|c|c|c|c|}
\hline Aug. & Star & Mag & Disap. & Reap. & $\begin{array}{l}\text { Corresponding } \\
\text { angles from ver- } \\
\text { tex to right for } \\
\text { inverted image }\end{array}$ \\
\hline $8 \ldots$ & 24 Scorpii. & $\ldots$ & $\begin{array}{rrrr} & \text { h. } & \text { m. } \\
& \text { I } & \text { I } & \end{array}$ & $\begin{array}{l}\text { h. m. } \\
2034\end{array}$ & ... $92255^{\circ}$ \\
\hline II $\ldots$ & $d$ Sagittarii & $\ldots 5$ & $\begin{array}{lllll}\ldots & \text { I8 } & 44 & \ldots\end{array}$ & 200 & ... 74242 \\
\hline Aug. & $\begin{array}{rrrr} & \text { h. } & \\
. & \text { r } 4 & \ldots\end{array}$ & $\begin{array}{l}\text { Venu } \\
\text { of }\end{array}$ & onjunction & witl & and $0^{\circ} \mathbf{I}^{\prime}$ south \\
\hline
\end{tabular}

\section{THE SCIENTIFIC DEVELOPMENT OF THE COAL-TAR COLOUR INDUSTRY ${ }^{1}$}

THE subject on which I propose to address you this evening has been brought under the notice of the Society of Arts on former occasions, and was only la t year thoroughly treated of by Dr. W. H. Perkin, the pioneer of this branch of manufacture, in his Presidential Address to the Society of Chemical Industry. It has, moreover, quite recently furnished materials for a lecture at the Royal Institution by Sir Henry Roscoe, so that I feel in some measure obliged to apologise for again bringing forward a topic upon which it may appear to chemists that nothing particularly new remains to be said. Having, however, been intimately associated with this branch of chemical industry for many years, I have had exceptional opportunities of watching its development, and of forming ideas upon the causes of its progress, which may justify my engaging your attention upon the present occasion.

The manufacture of coal-tar products is a subject which offers distinct advantage for popular treatment, both on account of the practical utility of the products, and the striking and beautiful colour phenomena which they present. But I do not propose now to avail myself of these advantages, because I think there is a more serious aspect of the subject than the mere enumeration of the names, chemical formulæ, and mode of preparation of the recently discovered products. I must take it for granted that those present this evening are familiar with the fact that out of coal-tar there are obtained series of hydrocarbons from which are prepared nearly all the dye-stuffs at present in use ; that the introduction of these artificial colouring-matters has revolutionised the tinctorial industries, and that the tar of gas-works, which was formerly a waste product and a nuisance, is now a valuable source of revenue to the gas companies. It is, doubtless, known to you also that, besides colouring-matters, there are obtained from the same hydrocarbons artificial perfumes, and drugs which rival quinine in efficiency; and that quite recently a substance has been discovered by Dr. Fahlberg, which goes by the name of "saccharine," and which is stated to possess 220 times the sweetening power of cane sugar. ${ }^{2}$ But I must content myself by merely pointing to such discoveries as triumphs which the chemist, by his "so potent art," has achieved in recent times, because I want to bring home to English manufacturers one particular point in connection with this industry, and the Chemical Section of the Society for the Encouragement of Arts, Manufactures, and Commerce seems to me to be the right place for so doing. It cannot be denied that the coal-tar industry has for some years past been migrating from this country, the land of its birth, to the continent of Europe. Of the causes of this decline assigned by Dr. Perkin and others who have expressed opinions upon the subject, I do not now propose to touch upon those which may be considered as purely politico-economical

${ }^{\mathrm{I}}$ A Paper read at the Society of Arts by Prof. R. Meldola, F.R.S., F.C.S., F. I.C., on May 13,1886 .

The substance referred to is an anhydro-derivative of orthosulphaminebenz sic acid having the formula

$$
\mathrm{C}_{6} \mathrm{H}_{4}<\underset{\mathrm{SO}_{2}}{\mathrm{CO}}>\mathrm{NH} \text {. }
$$

For details, see a paper by I. Levinstein, Joum. Soc. Chem. Ind., Feb. 1836, p. 75. Also the original communications in the American Chemical Fournal, vol. i. pp. 7 o and 426 , and vsl. ii. p. r8r. For an investigation of the physiological action see the Archivio per le scienze mediche, vol. ix. No. 22, p. 407 (Turin, r886).
Nothe 
ones, such as Free Trade, the Patent Laws, or the available energy of a British as compared with a German workman under the stimulus of a certain amount of weekly wage. These and kindred questions-such as the cost of railway carriage, or the relative ideas of "making a manufacture pay" which may exist in the British and Teutonic minds-have, doubtless, a most im portant bearing upon the main subject, but their discussion would occupy far too much time, and would, moreover, be out of place in this Section. I might even go so far as to express a private belief that if this portion of the subject were handed over for legitimate treatment by economists, the conclusions arrived at (if any) would hardly be commensurate with the amount of discussion which would be evoked. In fact, it appears to me that although, in a general way, each of the causes mentioned must be a factor in determining the success of any branch of manufacture, it is quite impossible to assign its true value to each of these factors; and in the case of the present industry I am persuaded that it is now a question of chemical and not of economic science that is pressing for consideration.

It will, I think, be conceded that the manufacture of coal-tar products is par excellence the most scientific of the chemical industries. This high position may fairly be claimed for the industry when we consider the number and complexity of the products, the delicacy of many of the reactions employed, the special arrangements of plant required, and the intimate knowledge of the chemistry of the aromatic compounds which the colour chemist must at the present time possess. Moreover, the industry is of comparatively recent grou th-it has been born and has reached its present development within the last thirty years, so that the successive phases of its evolution can be clearly traced. For these rea ons the subject is well calculated to throw light upon the general question of technical chemical education, a question of which the importance to the country at large now bids fair to become duly recognised.

In treating of the industrial development of a branch of chemical manufacture, it is important that we should begin with a distinct idea of the products themselves. I must claim the indulgence of chemists if at this stage $I$ find it necessary to go over s smewhat old ground, and to state facts with which so many are familiar. It would, of course, be quite impossible to give, on the present occasion, anything like a complete chronological list of the various colouring-matters, and it would be equally impossible for me to enter into the discussion of the chemical structure of the beautiful compounds which are now to be met with in the market. If, later on, I find it necessary to enter into questions of chemical constitution, it will be chiefly with the object of ilsustrating general principles by appealing to particular cases. In the brief historical sketch which I now propose to lay before you, I shall mention only those discoveries which may be considered to mark distinct commercial epochs in the development of the industry. The successive steps in this development will furnish us with one of the most striking illustrations of the utilisation of scientific discovery for industrial purposes, and the reaction of industry upon pure science.

Commencing in the year 1856 , the foundation of the coal-tar colour industry was laid by Perkin, by the discovery of mauve, a violet dye, obtained accidentally in the course of an investigation having for its object the preparation of quinine by an artificial synthesis. In 1860 , magenta, which had formerly been made in small quantities by expensive processes, was rendered a product of the first order of commercial importance by the discovery of the arsenic acid process by Medlock and E. C. Nicholson sumultaneously. During this same year phenylated blues were first produced by Girard and De Laire, by the action of aniline upon magenta base at a high temperature. These blues had sut a limited application owing to their insolubility, and their value was enormously enhanced by Nicholson's discovery, in 1862 , that these colours could be converted into soluble sulphonic acids. The first azo-colour, amidoazobenzene, a basic yellow dye, was introduced in 1863 by the firm of Simpson, Maule, and Nicholson, under the name of "aniline yellow." In this same year the methylic and ethylic derivatives of magenta were manufactured by the same firm under the name of "Hofmann violets," in honour of their discoverer. "Azodiphenyl blue," the first of the colouring-matters now known as indulines, and Manchester yellow, appeared in 1864; and in 1866 " Bismarck brown" (triamidoazobenzene) was first manufactured at Manchester. The same year (I866) was marked by the introduction of Coupier's nitro-benzene process for the manufacture of magenta.
In 1868 Graebe and Liebermann gave to the world their great discovery of the chemical constitution of alizarin, and in the following year the manufacture of this colouring-matter from anthracene was commenced. The first members of the great family of the "phthaleines," viz. gallein and fluorescein, were discovered by Baeyer in 1871; and the first technical application of this discovery was made in 1874 by Caro, who introduced the beautiful pink tetrabromfluorescein into commerce, under the name of "eosin." Diamidoazobenzene was discovered by Caro and Witt independently in 1875, and was introduced into commerce by the latter as "chrysoïdine." A great impetus was given to the technical production of azocolouring matters by this discovery, the naphthol oranges and other "tropoeolines," fast-red, the ponceau scarlets, \&c., appearing in 1878 . Methylene blue and acid magenta were introduced by Caro in 1877 , and in the same year the old and fugitive "aniline yellow" was converted into a valuable acid yellow by Grässler, who patented a process for converting the base into a sulphonic acid. Malachite green was introduced in I 878 , and in 1879 the first member of the now important group of secondary azo-compounds appeared under the name of Biebrich scarlet. It is these secondary azo-scarlets, and especially the "croceine scarlets" (discovered in 188I) which are exterminating the cochineal industry. The year 1880 was marked by the brilliant discovery of the constitution of indigo, and the synthesis of this colouring-matter by Baeyer, a discovery which is none the less a triumph of synthetical chemistry because the manufacture is not at present successful from a commercial point of view. Indophenols were introduced by Koechlin and Witt in $\mathrm{I} 88 \mathrm{I}$, and in $\mathbf{I} 883$ appeared Caro's first patent for the production of colouring-matters of the rosaniline group by the method of "condensation" with phosgene gas, in the presence of suitable condensing-agents.

This chronological record comprises nearly all the chief colouring-matters from coal-tar which are, or have been, of industrial value. It is important to note that the list, even as it stands in the form of a bald statement of facts in chemical history, reveals the existence of that fundamental law of the "survival of the fittest." Old products have been displaced by newer ones, as fresh discoveries were made, or processes improved, and to the chemist it is of interest to observe how this development of an industry has gone on pari passu with the development of the science itself. The moral conveyed to the manufacturer is sufficiently obvious. If we are to recover our former supremacy in this industry, we must begin by dispelling conservative ideas - we must realise the fact that no existing process is final, and that no product at present sent into the market is destined to survive for an unlimited period. The scientific manufacturer must be brought to see that present success is no guarantee for future stability, and unless he realises this position in its fullest significance, he may find the sale of his standard products gradually falling off, or be compelled to wake up to the unpleasant fact that his competitors are underselling him, owing to improved methods of manufacture.

It may appear to many that I am here simply preaching the doctrine of progress, and that the remarks which I have offered are mere truisms. Unfortunately, the facts of the case render this appeal necessary. It must never be forgotten that the coaltar colour industry is essentially of English origin. It was Faraday who first discovered benzene in 1825 ; it was Mansfield who, in 1847, first isolated this substance in large quantities from coal-tar, and showed how nitro-benzene could be manufactured therefrom. The beginning of the colour industry was Perkin's discovery of mauve ; and the introduction of the new colour into dyeing establishments was due to the example set by Messrs. Pullar, of Perth, in 1856 . The manufacture of magenta on a large scale was the result of the discovery of the arsenic acid process by Medlock and Nicholson; and the phenylic blues were made commercially valuable by Nicholson. The first azocolours, "aniline yellow " and "Manchester brown," as well as "Manchester yellow" (dinitro- $\alpha$-naphthol) were manufactured in this country. We may thus fairly lay claim to have given to the commercial world the types of all the more important colouring-matters of the present time. If, as is certainly the case, the development of these typical products has been allowed to take place in other countries, it behoves us, as a practical nation, to inquire closely into the cause of this success abroad-.a success which will appear all the more remarkable when we bear in mind that we are the largest European producers of the raw material, gas-tar, out of which the çolours are manufactured, 
as well as being among the largest consumers of the dyes themselves. It is estimated that the amount of tar distilled annually in this country is about 500,000 tons, and it is certain that we distil at least one-lialf of the whole a nount of tar produced in Europe. The present state of affairs is that our competitors can afford to import the raw materials from us, to manufacture and return the colours so as to conpete with us successfully in our own markets, and to undersell us in the foreign markets. The bare mention of these facts will be sufficient to indicate the existence of something requiring radical reform in our manufacturing system.

Before submitting to you the statistics of this industry which I have been able to collect, I think it desirable to make an attempt to show the inner mechanism by which chemical science has been and is being so successfully adjusted to commercial wants by our Continental neighbours. I regret exceedingly that my predecessors on this and other platforms have not left me the chance of giving a general sketch of the chemical development of the different groups of colouring-matters. In fact, I find myself suffering here from several distinct disadvantages, but I hope, with your forbearance, to make the best of the situation. It will serve my purp sse equally well, or perhaps even better, to confine my illustration to one particular group of colouring-matters. The more striking achievements, such as the syntheses of alizarin and indigo, are now so femiliar to chemical audiences that their repetition would be unnecessary. Equally instruetive, from the present point of view would be the history of the colouring-matters of the rosaniline group, and I can only express a passing regret that time will not permit me to recapitulate the steps in the beautiful series of investigations which led to the establishment of the structural formula of rosaniline and its derivatives by $\mathrm{E}$. and $\mathrm{O}$. Fischer, and then to the synthesis of these colours by Caro from ketone bases. The principle which I wish to bring out may seem a strange one to a "practical" psople, but I am convinced that the whole secret of success abroad is the spirit of complete indifference to immediately successful results in which the researches are carried on. I say " immediately successful " because it would of course be absurd on the part of an investigator not to take advantage of any discovery which happened to be of commercial value. But, as a general principle, the question of practical utility does not in the first place enter into the work. The great development of this and many other industries is mainly due to the complete and thorough recognition, on the part of our competitors, of the vital importance of chemical science. In this country, where the word "practical" threatens to become a reproach, we put science into the background, and attach all importance to the mere technique of our manufactures. If I might venture to offer an aphorism to the English manufacturer, it would be to the effect that he should look after the science, and leave the technique to take care of itself.

After these considerations, you will see that it is a matter of perfect indifference whether I take by way of illustration products which have been successful from a financial point of view or not. In order to give greater emphasis to the principle, I propose, however, to consider the history of some colouring. matters which have found a market value, and I select this group with the more readiness because, on the one hand, it was not treated of last year by Dr. Perkin, and, on the other hand, it furnishes a splendid illustration of the way in which these coal-tar products are being scientifically developed in the foreign laboratories.

In 1863, Mr. E. C. Nicholson discovered a basic orange colouring-matter among the by-products formed during the manufacture of magenta by the arsenic acid process. The method of isolating this substance in a state of purity was very skilfully worked out by Messrs. Simpson, Maule, and Nicholson, and the colour was introduced into the market under the name of "phosphine." This dye was the first basic orange discovered, and the advantages which it possessed for certain kinds of dyeing enabled the manufacturers to sell it at a price which helped to cheapen the cost price of magenta to an appreciable extent. The chemical composition of the substance was established in 1863 by Hofmann, who assigned the formula $\mathrm{C}_{20} \mathrm{H}_{17} \mathrm{~N}_{3} . \mathrm{H}_{2} \mathrm{O}$, and described the base under the name of chrysaniline. Although other and cheaper basic orange colouring-matters have since been discovered, chrysaniline still finds a distinct use ; and I am informed by Messrs. Brooke, Simpson, and Spiller that the amount of this colour now sold is not appreciably less than at the time of its introduction by their prede- cessors. The chemical constitution of chrysaniline remained unknown till about two years ago, when the problem was solved by $\mathrm{O}$. Fischer (Berichte, I884, p. 203). In order to be able to follow the steps in the investigation, it will be necessary, in the first place, to go back to the discovery of another colouringmatter, called flavaniline, of which the existence was made known by O. Fischer and C. Rudolph in $\mathbf{1} 882$ (Berichte, $\mathbf{1} 882$, p. 1500). Flavaniline was produced by the action of dehydrating agents, such as zinc chloride, upon acetanilide, this fact having been observed by Rudolph in $188 \mathrm{I}$, and the practical manufacture of the colour having been carried on under a patent by Messrs. Meister, Lucius, and Brüning, of the Hoechst colourworks. ${ }^{1}$ Supplied with a larse quantity of the pure crystalline material by the manufacturers, Messrs. Fischer and Rudolph established the formula of flavaniline, $\mathrm{C}_{16} \mathrm{H}_{14} \mathrm{~N}_{2}$, and showed that its formation from acetanilide might be expressed by the equation:-

$$
{ }_{2} \mathrm{C}_{6} \mathrm{H}_{5} \cdot \mathrm{NH} . \mathrm{C}_{2} \mathrm{H}_{3} \mathrm{O}-2 \mathrm{OH}_{2}=\mathrm{C}_{16} \mathrm{H}_{14} \mathrm{~N}_{2} \text {. }
$$

By the action of nitrous acid upon flavaniline a diazo-compound was produced which, by the usual method of decomposition by water, gave a phenolic derivative termed flavenol, and possessing the formula $\mathrm{C}_{16} \mathrm{H}_{12} \mathrm{~N} . \mathrm{OH}$, thus proving that flavaniline contained a displaceable $\mathrm{NH}_{2}$ group. By heating flavenol with zirc dust, a base was obtained having the formula $\mathrm{C}_{16} \mathrm{H}_{13} \mathrm{~N}$, and termed flavoline. This base had an odour resembling that of quinoline, and all its properties suggested to the authors that flavaniline was in reality a quinoline derivative. That flavaniline was amido flavoline was proved by nitrating the latter base, and reducing the nitro-compound, when flavaniline was obtained. In a later publication by Besthorn and Fischer (Birichte, 1883 , p. 68) it was announced that flavenol, when oxidised by potassium permanganate in an alkaline solution, gave an acid which, on distilling with lime, furnished a base having all the characters of lepidine. By the continued oxidation of flavenol with excess of alkaline permanganate, another acid was obtained, which proved to be picoline-tricarb snic acid, and the latter, on further oxidation, gave picoline-tetracarbonic acid (Berichte, I884, p. 2925).

So much for the facts; now for their interpretation. The production of flavenol from flavaniline by the diazo-reaction shows that the respective formulas of these substances are :-

$$
\mathrm{C}_{16} \mathrm{H}_{12}\left(\mathrm{NH}_{2}\right) \mathrm{N} \quad \mathrm{C}_{16} \mathrm{H}_{12}(\mathrm{OH}) \mathrm{N} \text {. }
$$

Flavenol gave, as the first product of oxidation, lepidine-carbonic acid, of which the formula is $\mathrm{C}_{10} \mathrm{H}_{8} \mathrm{~N}\left(\mathrm{CO}_{2} \mathrm{H}\right)$, and by further oxidation it gave picoline-tricarbonic acid, of which the formula is $\mathrm{C}_{6} \mathrm{H}_{4} \mathrm{~N}\left(\mathrm{CO}_{2} \mathrm{H}\right)_{3}$. Now the $\mathrm{C}$-atoms oxidised by the breaking down of the $\mathrm{r} 6$-carbon atom flavenol into I $\mathrm{I}$-carbon atom lepidine-carbonic acid, are those $\mathrm{C}$-atoms which in flavenol are associated with the hydroxyl group, because this group is no longer contained in the product of oxidation. Thus the formulas of flavaniline, flavenol, and flavoline are better expressed as :-

$$
\begin{aligned}
& \mathrm{C}_{10} \mathrm{H}_{8} \mathrm{~N} \cdot \mathrm{C}_{6} \mathrm{H}_{4}\left(\mathrm{NH}_{2}\right) \\
& \mathrm{C}_{10} \mathrm{H}_{8} \mathrm{~N} \cdot \mathrm{C}_{6} \mathrm{H}_{4}(\mathrm{OH}) \\
& \mathrm{C}_{10} \mathrm{H}_{8} \mathrm{~N} . \mathrm{C}_{6} \mathrm{H}_{5} .
\end{aligned}
$$

From this it appears that flavaniline is amidophenyl-lepidine, flavenol hydroxyphenyl-lepidine, and that flavoline is phenyllepidine.

The central nucleus of flavaniline having thus been shown to be lepidine (which is methylquinoline), the next question to be settled was the mode of formation of the colour base from acetanilide. The authors suggest that at the high temperature of the reaction, acetanilide, in the first place, becomes transformed into the isomeric orthoamidoacetophenone :-

$$
\begin{array}{rr}
\mathrm{H} \cdot \mathrm{CH}_{3} & \stackrel{\mathrm{CH}_{3}}{\dot{\mathrm{C}}: \mathrm{O}} \\
\mathrm{C}_{6} \mathrm{H}_{5} \cdot \dot{\mathrm{N}} \cdot \dot{\mathrm{C}}: \mathrm{O} & \mathrm{C}_{6} \mathrm{H}_{4} \\
\text { Acetanilide. } & \text { Amidoacetophenone. }
\end{array}
$$

By the condensation of two molecules of the amidoacetophenone with the elimination of two molecules of water, flavaniline would be produced in a manner analogous to the forma tion of mesitylene by the condensation of three molecules of acetone under the influence of dehydrating agents :--

${ }^{x}$ I am indebted to this firm for having kindly supplied me with specimens of these products for exhibition. 


$$
\begin{aligned}
& \mathrm{C}_{6} \mathrm{H}_{4}\left\langle\begin{array}{l:lll}
\mathrm{C}=\mathrm{C} & \mathrm{O} \quad \mathrm{H}_{2} & \mathrm{CH} \\
\mathrm{H}_{2} \mathrm{O}= & \mathrm{C}-\mathrm{C}_{6} \mathrm{H}_{4} \cdot \mathrm{NH}_{2}=
\end{array}\right. \\
& \begin{aligned}
\stackrel{\mathrm{CH}_{3}}{\dot{\mathrm{C}}}=\underset{\mathrm{CH}}{\mathrm{C}} \\
\mathrm{C}_{6} \mathrm{H}_{4} \backslash \underset{\mathrm{N}}{\mathrm{C}}-\mathrm{C}_{6} \mathrm{H}_{4} \cdot \mathrm{NH}_{2}
\end{aligned}+2 \mathrm{OH}_{2}
\end{aligned}
$$

The accuracy of this suggestion was verified by showing that orthoamidoacetophenone is present in small quantity when the reaction is arrested as soon as the formation of colouring-matter commences; and conversely, when pure orthoamidoacetophenone was heated with zinc chloride, flavaniline was produced in small quantity. ${ }^{1}$

We may be permitted to pause at this stage of the investigation, before proceeding to consider the connection of this work with the constitution of chrysaniline. These results cannot but be regarded by chemists as a very beautiful piece of investigation; but the person of a "practical " turn of mind may possibly want to know what bearing they have upon the question of market value-the question which the manufacturer but too frequently considers as the only one of importance. Now it is the essence of chemical science-as indeed of all other sciences - that every discovered fact is related to other groups of facts, and although the relationship may not at once be apparent, it is only a matter of further development that is necessary in order to reveal relationships which are at present obscure on account of our imperfect knowledge. Thus, the policy of looking at a chemical product from the narrow point of view of immediate utility is not only unscientific, but it is detrimental to the interests of the manufacturer himself. Every new compound or process discovered-every structural formula established by legitimate investigation, may have an enormous influence, directly or indirectly, upon the market value of products at present sent into commerce. Our manufacturers must realise this if they wish to recover their position in the coal-tar industry, or in fact in any other chemical industry. There is no branch of manufacture so perfect as not to be open to further improvement, and until the broad spirit of scientific development is made to replace the suicidal policy of immediate utility, our position as a manufacturing nation is not likely to be improved.

In order to justify this digression by the particular instance now under consideration, we must return to the work of Messrs. Fischer and Besthorn. The discovery that flavaniline was a quinoline derivative was of importance as a principle, quite apart from any immediate value attaching to the dye-stuff itself. Up to the time of this discovery, the quinoline derivatives, with the exception of alizarine blue, had been practically of no importance in the tinctorial industries, but as a consequence of the present investigation, the question at once suggested itself whether the analogous bases of high boilingpoint, which are present in coal-tar, such, for example, as acridine, might not be utilised as sources of colouring-matters. I may remind you that the fact of quinoline being an aromatic compound was first established by the researches of our Chairman this evening, Prof. Dewar, who obtained aniline from this base. In a subsequent paper on chrysaniline ( $O$. Fischer and G. Körner, Berichte, I884, p. 203), it was pointed out that in the course of his investigations upon rosaniline Fischer had observed that the former base, like rosaniline, was capable of furnishing a diazo-compound. An observation made by Claus is also mentioned, viz. the conversion of chrysaniline into a phenol (chrysophenol) by heating to a high temperature with hydrochloric acid in accordance with the equation :- -

$$
\underset{\substack{\text { Chrysaniline } \\ \text { hydrochloride. }}}{\mathrm{C}_{16}} \underset{\text { Chrysophenol. }}{\mathrm{H}_{15} \mathrm{~N}_{3} . \mathrm{HCl}}+\mathrm{H}_{2} \mathrm{O}=\underset{\mathrm{NH}_{4} \mathrm{Cl} .}{\mathrm{C}_{19} \mathrm{H}_{15} \mathrm{~N}_{2} \mathrm{O}}+\mathrm{NH}^{\text {. }}
$$

The investigation of flavaniline appears to have given an impetus to the ideas respecting chrysaniline, because of the general similarity in the properties of these two substances. In confirmation of this impression, it was found that by the oxidation of chrysophenol an acid was obtained which, on distil-

${ }^{2}$ Just after writing this palver, a new contribution to the chemistry of flavaniline was published by $\mathrm{O}$. Fischer (Berichte, 1886, p. x०36), from which it appears that the condensation is really between one molecule of ortho- and one molecule of fara-amidoacetophenone, the latter being produced by the isomeric transformation of the ortho-compound at the high temperature employed. The constitution of flavaniline is thus definitely established as paraamidophenyl- $\gamma$-lepidine. lation with lime, gave a pyridine base. I need hardly remind you that picoline, which was obtained from the acid resulting from the extreme oxidation of flavenol, is methylpyridine. It was thus established that chrysaniline was a derivative of a quinoline base.

The next step in the investigation is a very important one. By decomposing the diazo-compound of chrysaniline with alcohol according to the Griess reaction, phenylacridine was obtained. Acridine is a base belonging to the quinoline series, having the formula $\mathrm{C}_{13} \mathrm{H}_{9} \mathrm{~N}$. It was discovered by Graebe and Caro in 1872 in crude anthracene. Phenylacridine accordingly possesses the formula $\mathrm{C}_{13} \mathrm{H}_{8} \mathrm{~N}, \mathrm{C}_{6} \mathrm{H}_{5}$; and chrysaniline appears as diamidophenylacridine, $\mathrm{C}_{13} \mathrm{H}_{7}\left(\mathrm{NH}_{2}\right) \mathrm{N} . \mathrm{C}_{6} \mathrm{H}_{4}\left(\mathrm{NH}_{2}\right)$, because two amido groups are replaced by $\mathrm{H}$ by the diazo reaction. Thus the formula $\mathrm{C}_{20} \mathrm{H}_{17} \mathrm{~N}_{3}$ (first assigned by Hofmann to chrysaniline) is really the formula of the higher homologue, chrysotoluidine.

In order to explain the formation of chrysaniline during the oxidation of the materials (aniline and toluidine) in the "red melt" still, several suggestions were put forward, of which the most probable appeared to be that the base was derived from triamidotriphenylmethane, the latter compound resulting from the condensation of two molecules of aniline with one of orthotoluidine :-

$$
\begin{aligned}
& \mathrm{C}_{6} \mathrm{H}_{4} \backslash \mathrm{CH}_{3} \mathrm{NH}_{2}+{ }_{2} \mathrm{C}_{6} \mathrm{H}_{5} \cdot \mathrm{NH}_{2}-2 \mathrm{H}_{2}= \\
& \mathrm{HC}\left(\mathrm{C}_{6} \mathrm{H}_{4} \mathrm{NH}_{2}\right)_{3}
\end{aligned}
$$

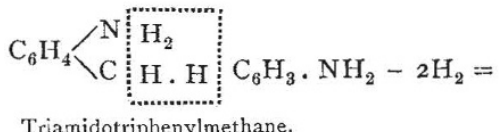

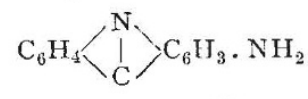

$\mathrm{C}_{6} \mathrm{H}_{4} \cdot \mathrm{NH}_{2}$

Diamidophenylacridine $=$ Chrysaniline

The relationship of chrysaniline to the colouring-matters of the rosaniline group is thus indicated ; but, tempting as is this theme, time will not admit of further digression into this field. The main point, so far as we are at present concerned, is that by means of the present investigation, we have now arrived at a knowledge of the parent substance, acridine, of which a colouring-matter more than twenty years old proves to be a derivative By such results new fields of investigation are opened up, and direct methods for the production of chrysaniline suggest themselves. Even the practical requirements wonld be satisfied if i could be shown that the colour could be manufactured cheaply by a direct synthesis, instead of depending, as heretofore, upon the small and capricious secondary product of the magenta manufacture. As a matter of fact several syntheses of chrysaniline have been effected, one of which forms the subject of a patent (German Patent, 29r42, April 1884) by Messrs. Ewer and Pick, of Berlin. Into the mode of preparation by this patented process I cannot now enter any further than by merely stating that nitrodiphenylamine and nitrobenzoylchloride form the starting-points, and that the specification bears the title"Preparation of chrysaniline and other colouring-matters of the phenylacridine group." If an elaborate scientific investigation culminates in a patent, its utility will, I know, be conceded by many for whom the work would otherwise have possessed no particular interest.

The illustration which I have given is a typical example of the kind of scientific development which is being carried on by our chemical colleagues abroad, and which is being taken advantage of in the Continental factories. I do not wish to give you the impression that the particular colouring-matters dealt with are of supreme importance industrially-they are of considerable importance, but the modern history of any other colouringmatters would have been equally instructive. The beautiful researches of Bernthsen upon the constitution of methylene blue, would have done equally well had time permitted of my making use of them. It seemed to me more appropriate to this Section of the Society of Arts to give a somewhat detailed account of one particular series of investigations, rather than to take a skim over the mere surface of the enormous field which the coal-tar 
colour industry now offers. The case considered at any rate presents the advantage of not being too hackneyed, and this will be sufficient excuse for having made use of it.

It was stated at the commencement of this paper that there is reason to believe that our supremacv in the coal-tar colour industry has, for some years, been declining, and I have further expressed my belief that the chief cause of this falling off is the subordinate position given to chemical science in this country as compared with the status of this science abroad. Whether this explanation be accepted or not, the fact of the decadence of the manufacture remains, and $I$ am in a position to bring this unpleasant truth home to our countrymen by a strong body of evidence. It must be borne in mind that the decline of any industry cannot be measured by the absolute weight of the products turned out annually, because the demand for the products in question may be on the increase, and we may be actually producing a greater weight of colours now than we were during our most successful period. The whole question is a relative one-it is simply how much material are we now turning out as compared with the amount produced by our competitors-what proportion of coal-tar products do we supply for our own and foreign consumption? In order to answer this question with some approach to numerical exactness, it occurred to me that the most trustworthy information could be obtained from the consumers themselves ; and through the kindness of Mr. Robert Pullar, of Perth, and Mr. Ernest Hickson, of Bradford, I have been enabled to put myself into communication with several of the representative dyeing an $t$ printing establishments of this country. The facts obtained, as showing the actual state of the industry at the present time, appear to me of sufficient interest to be given here in some detail. I may take the present opportunity of stating that my application for statistical information has been most courteously responded to by the various firms, to whom I have great pleasure in returning my thanks.

Edward Ripley and Son, of Bradford, perhaps the largest dyers of piece-goods in the kingdom, inform me that during the year 1885 they used $86 \frac{1}{2}$ per cent. of foreign coal-tar colours, and $13 \frac{1}{2}$ per cent. of English make.

Walter Walker and Son, of Dewsbury, dyers of wool for rugs, mats, carpet yarn, and blanket stripes, estimate that during I 885 they used 80 per cent. of German dyes. They state that the exact proportion is difficult to estimate, so that the figure given is only approximative. Referring to their larger consumption of foreign colour they state :- "It is very discouraging to have to do this and send the trade out of our country, but to our own interest and advantage we have to do it."

John Newton, silk dyer, Macclesfield. Mr. Walter Newton, F.C.S., informs me that during 1885 they used 80 per cent. of foreign colour. He adds :- "The rapid advancement in the improved manufacture of some of these dyes by the Germans is the only cause of our desertion from the English colour-manufacturer."

G. W. Oldham, silk dyer, of Netherton, near Huddersfield, informs me that during $\mathbf{1} 885$ he used 2000 ibs. of German dyes, I 100 lbs. of English dyes, and 800 lbs. of doubtful origin.

James Templeton and Co., of Glasgow, state that they dye as much as 30,000 lbs. of yarn (chiefly worsted) weekly, but they use only a small proportion of coal-tar dyes, all of which are of German manufacture.

Messrs. Leckie and MacGregor, of Paisley, inform me that in the west of Scotland, including Glacgow and Paisley, they are certain that at least 90 per cent. of the dyes used come from the Continent. Their own consumption of English colour only reached 6.8 per cent.

Alexander Harvey and Son, of Glasgow, yarn dyers, state that during 1885 they used 60 per cent. of German and 40 per cent. of English dyes. These figures do not include alizarin, of which they state that they used about equal quantities of German and English make. The English supply is chiefly made up of one article, "aniline salt." They add :- "We find the German makes in general of better value than the British, as our rule is, ceteris paribus, to give the home-make the preference."

Messrs. Manson and Henry, Glasgow, yarn dyers, state that they use only German dyes, adding that they find it to their advantage "for both cheapness and quality."

Among the largest consumers of coal-tar colours in this country are the jute dyers. As representing this department of the tinctorial industry, Messrs. James Stevenson, of Dundee, inform me that during 1885 they used only 7.7 per cent. of English colour. They have been good enough to supply the fo:l wing analysis of their consumption:-

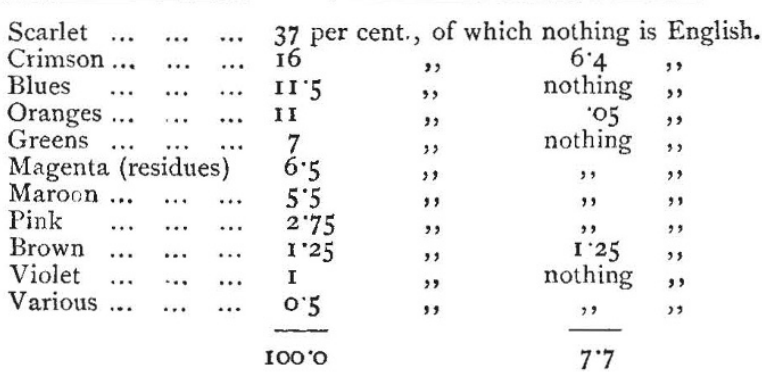

Messrs. Cox Bros., of the Camperdown Jute Works, Lochee, state that practically the whole of the "aniline" colours used by them are of Continental manufacture.

With reference to the calico printers, the following facts have been collected :-

Messrs. Z. Heys and Sons, of Barrhead, state that during I 885 they used over Io, 000 lbs. weight of colours (exclusive of alizarin), of which 7oo lbs. only were of English make.

Messrs. James Black and Co., of Bonhill, Dumbartonshire, state that in their belief more than one-half of the colour used by calico printers is of foreign manufacture.

In the course of the present inquiry, it seemed desirable to obtain information concerning the consumption of alizarin, with reference to which the following statements have been received :-

Messrs. Waiter Crum and Co., of Thornliebank, Glasgow, are of opinion that "the great bulk of what is used in this country is manufactured in Germany." They do not profess to be able to give actual figures having any approach to accuracy.

Mr. John Christie, of the Alexandria Turkey-Red Works, Dumbartonshire (John Orr, Ewing, and Co., states that they use on'y artificial alizarin in their establishment, their consumption being considerably over $2,000,000$ lbs. weight of ro per cent. paste annually. Their consumption was, in-

\begin{tabular}{|c|c|c|c|c|c|c|c|c|}
\hline r 880 & $\ldots$ & 98 & cen & erman & $\ldots$ & & cent. & English \\
\hline $\mathbf{I} 88 \mathbf{I}$ & $\ldots$ & 99 & ," & , & $\ldots$ & I & , & ", \\
\hline I 882 & $\ldots$ & 100 & ", & ," & $\ldots$ & o & ", & , \\
\hline 1883 & $\ldots$ & 77 & ," & , & $\ldots$ & 23 & , & , \\
\hline 1884 & $\ldots$ & 56 & $"$ & ", & $\ldots$ & 44 & , & , \\
\hline 188 & $\ldots$ & 47 & , & ," & $\ldots$ & 53 & ", & , \\
\hline
\end{tabular}

Messrs. William Stirling and Sons, of Glasgow, state that their relative consumption of English and German alizarin for Turkey-red dyeing varies so much from year to year that they have no means of directly supplying useful data. This firm has, however, been good enough to make inquiries for me from a competent authority, who has furnished the following report :-

"In I 883 and I884 I-estimate that the sales in the United Kingdom amounted to a monthly average of about 530 tons, Io per cent. (say 6360 tons, Io per cent. per annum). Of this quantity $I$ estimate about $30-33$ per cent. was manufactured in this country. Taking 1884 alone, the figures are estimated at 566 tons, Io per cent. per month (say 6800 tons, Io per cent. per annum). Proportion manufactured in Great Britain, say about $30-35$ per cent. In 1886 the consumption may be estimated at 550-600 tons, ro per cent. per month (say 6900 tons, Io per cent. per annum). Proportion manufactured in this country probably now very considerably more than 35 per cent."

This estimate of the total consumption (550-600 tons, Io per cent. per month) is confirmed by my friend $\mathrm{Mr}$. Thomas Royle, F.C.S., of the British Alizarin Company's works at Silvertown, but he is of opinion that 50 per cent. of this is of English manufacture.

By way of further confirmation, it appeared to me to be desirable to get the opinion of manufacturers themselves, and although this has been a matter of considerable difficulty, I am able to give some kind of an estimate. Mr. Ivan Levinstein, of Manchester, estimates that Germany produces :-

Colours derived from benzene and toluene, six times more than England.

Colours derived from naphthalene, seven times more than England.

Colours derived from anthracene, five times more than England.

The average production of Germany is thus about six times that of this country. Mr. W. A. Mitchell, of the firm of W. C. Barnes and Co., Phœenix Works, Hackney Wick, informs 
me that of some 159 tons of "aniline" dyes which passed through their hands as agents last year, 95 per cent. were of Continental make. With reference to the two chief raw materials, benzene and aniline, this same firm estimates that about 75 per cent. of the whole quantity of these products made in England goes to the Continent. ${ }^{1}$

The facts and figures which I have now laid before you must be left to tell their own story-time will not permit me to attempt any analysis of them. The evidence collected will at any rate give a much more forcible idea of the true state of the coal-tar colour industry in this country than has hitherto been attempted, and if this evidence goes against us as a manufacturing nation, it is all the more desirable that our true position should be realised. I find that it is almost impossible to give a correct numerical expression in pounds sterling for the annual value of this industry to the country, as the estimates vary within very wide limits. According to Dr. Perkin, whose opinion on this matter will perhaps carry the greatest weight, the value of the annual output is between $3,000,000 \mathrm{l}$. and 4,000,000l. That the industry is one of considerable importance on the Continent may be gathered from the official returns relating to the German exports. For the following figures $\mathrm{I}$ am indebted to Dr. $\mathrm{H}$. Caro, of the "Badische Anilin und Soda Fabrik," Ludwigshafen on Rhine :-

Exported from Germany, from Fanuary $\mathrm{r}$ to December 31, 1885

Alizarin paste (? per cent.)

A niline and intermediate products $\ldots 4283$ tons

Aniline, \&c., colours ... $\quad \ldots . . . .64645$,

Dr. Caro adds that it is generally believed that about fourfifths of the entire German production are exported.

The magnitude of this branch of chemical industry abroad will be gathered from the fact that a German factory of about the third magnitude consumes at the present time between 500 and 600 tons of aniline annually. According to information recently furnished to me from the two largest of the German factories, the Badische Company employ 2500 working men and officials, and the Hoechst Colour Works (formerly Meister, Lucius, and Brüning) r 600 working men and fifty-four chemists. It must, of course, be borne in mind that in these factories the products are not " aniline" colours only, but alizarin, acids, alkalies, and all chemicals required in this branch of manufacture.

The industry which has been selected for this evening's topic is thus not only an important one in itself, but for us, as chemists, its development is fraught with meaning both scientifically and educationally. In taking up this subject it has not been my desire to exalt the coal-tar colour industry to a position of undue importance, nor do I wish it to be inferred that the remarks which I have made concerning its decadence, or at any rate stagnation, in this country are applicable to this manufacture only. The failure on our part to grasp the true spirit of chemical science in its relation to our manufactures makes itself felt in every industry in which chemistry is concerned. The strength of our competitors is in their laboratories, and not, as here, upon the exchanges. It is only by showing up our weakness in each industry that the state of affairs can be remedied, and our prestige as a manufacturing country restored. If each specialist would do for his industry what I have here attempted to do broadly for the coal-tar colour industry, we should get together a body of evidence which the Royal Commissioners on the depression of trade would do well to take into consideration. We have heard a great deal of late years about the subject of technical education, but the talk has been rather one-sided. We have had utterances from those who, recognising the enormous importance of this subject to the country, have munificently endowed those institutions for the promotion of technical education which are springing up around us; we have had all kinds of schemes from those who are taking upon themselves the duties of technical educators, but it appears to me that we have not heard with sufficient distinctness the voices of those who may be presumed to suffer most from the want of technical education, viz. the manufacturers themselves. I have heard rumours of the existence of a certain class of manufacturer-let us hope a

I According to a later estimate, kindly supplied by Mr. Ivan Levinstein, the quantity of benzene and toluene used in this country amounts to about 500,000 gallons, and that used in Germany to about 2,000,000 gallons annually. A bout half the English production is, however, exported as aniline toluidine, and aniline salt, while Germany converts into colouring-matters at least $1,600, \infty 00$ gallons of these hydrocarbons. rare species-who declares that science is no use to him, and that he can get along better without it. I must confess that I never met this individual in the flesh, but I know that he exists in some of our manufacturing centres. As a species he is, however, doomed to extinction in the struggle with his competitors, and we may consider him out of court in the discussion of schemes of technical education. It is now generally admitted that the days of empiricism have passed away, and most manufacturers admit that present success and future development depend upon a proper recognition of technical, i.e. of applied science. But unless the manufacturers themselves speak loudly on this question, the voices of those who wish to promote scientific education may be drowned by the clamour of mere theorists.

In no other department of our manufactures is the want of technical science more felt than in the chemical industries. We not only see this in the greater development of these industries abroad, but in some of our most successful factories here-and this applies more especially to the coal-tar colour industryforeign chemists are employed, and as I have lately been informed by a well-known manufacturer, it is even impossible to get the necessary plant properly made in this country. There is no doubt that the recondite character of the truths of chemical science, as compared with the more obvious truths of mechanics and physics, has much to do with the want of popularity of this branch of knowledge, and is responsible for the circumstance that our science is regarded with comparative indifference until some branch of manufacture is in extremis. In our national characteristic of being "practical," we are apt to become shortsighted in our manufacturing policy, and to recognise only actualities, to the exclusion of the potentiality conferred upon a nation by a broader scientific culture.

In conclusion, I have to express my thanks to Messrs. Brooke, Simpson, and Spiller; Messrs. Burt, Bolton, and Haywood; and to the British Alizarin Company for the fine series of specimens now exhibited. For the beautiful specimens illustrating the Continental manufacture, I am especially indebted to the Badische Anilin and Soda Fabrik, of Ludwigshafen on Rhine, and to the Hoechst Colour Works. The series of patterns dyed with known weights of fifty distinct coal-tar colours were prepared by Mr. Ivan Levinstein for the lecture recently delivered at the Royal Institution by Sir Henry Roscoe, to whom I am indebted for being able to show them on the present occasion.

\section{DRYING UP OF SIBERIAN LAKES}

THE rapid drying up of lakes in the Aral-Caspian depression, in so far as it appears from surveys made during the last hundred years, is the subject of a very interesting and important paper contributed by M. Yadrintseff to the last issue of the Izvestia of the St. Petersburg Geographical Society (vol. xxii. fasc. I). Two maps, which will be most welcome to physical geographers, accoinpany the paper. One of them represents the group of lakes Sumy, Abyshkan, Moloki, and Tchany, in the Governments of Tobolsk and Tomsk, according to a survey made in 1784 . The other represents the same lakes according to three different surveys made during our century, in 1813 to 1820 , in 1850 to 1860 , and finally in 1880 , and it shows thus the rapid progress of drying up of these lakes. There are also earlier maps of Lake Tchany, which represent it as having very many islands (Pallas estimated their number at seventy), but they are not reliable. As to the map of 1784 , no cartographer, accustomed to distinguish "nature-true" maps from fancy ones, would hesitate in recognising it as quite reliable as to its general features. It is also fully confirmed by the ulterior detailed surveys dating from the beginning of our century. It appears from this series of four maps, dating from different periods, that the drying up has gone on at a speed which will surely appear astonishing to geographers. The group of lakes consisted of three large lakes-Sumy, Abyshkan, and Tchany, with a smaller lake, Moloki, between the two latter. Lake Tchany (the largest of the three) has much diminished in size, especially in its eastern and southern parts; but the greatest changes have gone on in the other lakes. Whole villages have grown on the site formerly occupied by Lake Moloki, which had a length of twenty miles at the end of last century, and now is hardly three miles wide. Of Lake Abyshkan, which had a length of forty miles from north to south, and a width of seventeen miles in the earlier years of this century, and whose surface was estimated at 530 square miles, 